\title{
Cover crops prove effective at increasing soil nitrogen for organic potato production
}

\author{
Organic crops command high wholesale prices, but organic management of nutrient deficiencies \\ and pests can be a challenge.
}

by Rob Wilson, Darrin Culp, Skyler Peterson, Kevin Nicholson and Daniel Geisseler

\begin{abstract}
nterest in using organic cover crops and soil amendments is rapidly increasing in California as organic acreage expands. In the northeast corner of the state, several Klamath Basin producers are experimenting with transferring substantial acreage to organic production. Crops commonly grown in rotation in the area include small grains, fresh-market potatoes and alfalfa. In 2016, over 4,200 acres of potatoes and 13,100 acres of wheat were produced organically in California (USDA 2017).

Prices for wholesale organic crops are regularly higher than prices for conventional crops (Klonsky and Greene 2005). In the case of fresh-market potatoes, organic prices can exceed $185 \%$ of conventional prices (USDA 2017). On the other hand, organic management of nutrient deficiencies and pest problems is challenging. Nitrogen is a limiting nutrient in many California soils, especially when potatoes and grass crops are grown in multi-year rotations (Lynch et al. 2012). Most potato varieties require at least 200 pounds of nitrogen per acre, from all sources, to maximize yield and quality (Lazicki et al. 2016). Potatoes also require a steady
\end{abstract}

\section{Abstract}

Many farms in northeast California are experimenting with organic production to take advantage of price premiums and niche markets. A common challenge in organic farming is finding dependable nitrogen sources to meet the needs of vegetable and grass crops, especially in fields with low soil nitrogen. This study assessed the use of cover crops and organic amendments for increasing soil nitrogen for potato production at the Intermountain Research and Extension Center in Tulelake. Researchers evaluated several cover crop species, three planting dates and multiple cover crop mixes. Amendments included composts, manures, bloodmeal and soymeal. The data collected in the study included total nitrogen from cover crops and amendments, plant-available nitrogen in the soil, potato petiole nitrate and crop yield and quality. Vetches and field peas, managed as green manure, were successful at satisfying potatoes' in-season nitrogen demand. These cover crops, grown alone or in mixes with non-legume species, produced potato crops whose yield and quality were similar to crops grown with conventional fertilizers. The cover crops' influence on potato pest pressure was neutral. Chicken manure was the most cost-effective amendment for satisfying potatoes' in-season nitrogen demand.

Fall cover crops shortly

before harvest and incorporation. According to UCCE researchers. vetches and field peas helped produce potato crops whose yield and quality were similar to crops grown with conventional fertilizers. 
Planting a spring cover crop trial at IREC. As part of the research project, cover crop species such as grasses, vetches, field peas and mustards, as well as mixes of these species, were planted in spring, mid-summer and fall. Potatoes were planted the year after cover crops were grown. source of nitrogen throughout the growing season to prevent yield reductions and physiological disorders (Stark et al. 2004).

Common organic farming practices for increasing soil nitrogen include using certified amendments, such as manures, or growing cover crops (Finckh et al. 2006). Manure, compost and organic fertilizers derived from animal and plant matter contain several plant nutrients, including nitrogen (Möller 2018). Manures are especially beneficial to soils deficient in phosphorus or potassium because the percentages of phosphorus and potassium found in most manure types are similar to or greater than the percentage of nitrogen found in the same manure type (Duru 1987). Cover crops have long been identified as beneficial to soil health because of their ability to increase soil carbon, decrease soil erosion and increase water infiltration (Kaspar and Singer 2011). Cover crops also influence soil nutrient recycling and nutrient availability. This is especially true of legumes - which, through a symbiotic relationship with bacteria, fix atmospheric nitrogen (Fageria et al. 2005). When legume leaves and stems decompose, plant-available nitrogen is added to the soil (Sincik et al. 2008).

A challenging aspect of using amendments and cover crops to fertilize potatoes is accurately predicting when the nitrogen in these products will become available to the crop (Sullivan and Andrews 2012). Adequate nitrogen must be available at potato planting to support vegetative vine growth and tuber set, while nitrogen availability in mid-summer is critical for tuber bulking (Alva 2004). Nutrient mineralization is driven by the decomposition of organic compounds into soluble inorganic forms that are available to plants (Whalen 2014). Since cover crops and manures are composed of organic material, farmers rely on the mineralization process to draw from these products plant-available

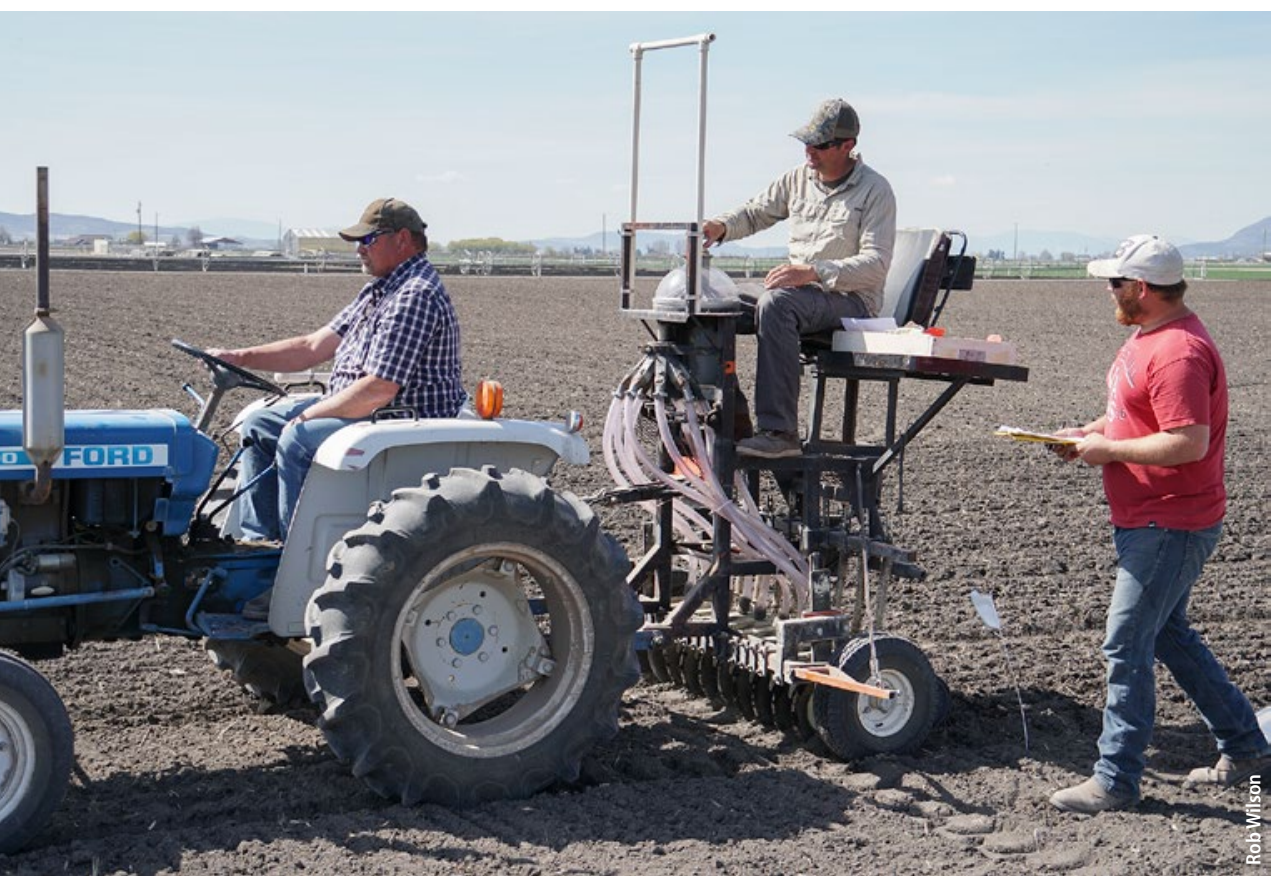

nitrogen that can feed their crops. Many factors influence a material's mineralization, including the carbonto-nitrogen ratio of the material, soil temperature, soil moisture and soil type. Accurate mineralization estimates require field testing under local conditions (Hartz et al. 2000).

Cover crops can have a positive or negative influence on potato pests such as weeds, nematodes, diseases and insects (Wyland et al. 1996; Larkin et al. 2010). Several plant species in the Brassica genus have been shown to produce high levels of glucosinolates, which can facilitate biofumigation when incorporated into the soil (Gimsing and Kirkegaard 2009). Oilseed radish has been shown to serve as a trap crop for cyst nematode (Hemayati et al. 2017). Some cover crops can promote potato diseases and nematodes by serving as a host and green bridge (Sharma-Poudyal et al. 2016). ("Green bridge" is the term applied to green plant material from volunteer plants, weeds and cover crops in which pathogen inoculums and pest populations increase between harvest of one crop and emergence of a newly planted crop.)

Barriers to widespread use of cover crops and other organic amendments in potatoes include costs related to materials, labor, transportation and application. Cover crops require time and resources to manage and do not provide the benefit of crop revenue. In urban areas, strong odors from manures are a disincentive (Larney and Blackshaw 2003). Cover crops and amendments with a high carbon-to-nitrogen ratio, such as grasses and brown composts, can often lead to a temporary immobilization of plant-available nitrogen (Sullivan and Andrews 2012), which is the opposite of the effect that potato growers are pursuing. In northeast California, nitrogen immobilization and the opportunity cost of cover cropping can be particularly problematic because growers have a small window of frost-free days in which to grow crops.

\section{Structure of research}

For this research project, multiple studies were conducted from 2014 to 2017 at the UC ANR Intermountain Research and Extension Center (IREC) in Tulelake, Siskiyou County, to evaluate the influence of cover crops, amendments and combinations of the two in a potato crop grown without synthetic fertilizers and pesticides. All cover crop and amendment trials were conducted alongside control treatments that included an unamended control as well as urea applications of 75 and 150 pounds of nitrogen per acre. All treatments were replicated four times. The primary study objective was to quantify the effect of cover crops and amendments on soil fertility, potato yield and potato pests.

\section{Cover crops}

Two cover crop studies were conducted at IREC - a study begun in 2014 that evaluated mid-summer cover crops and a study begun in 2016 that evaluated cover 
crops planted in spring, mid-summer and fall. Cover crop planting times and species were selected to fit local cropping systems and to maximize biomass production under local growing conditions. For example, planting cover crops in mid-summer is desirable for producers growing a grain hay crop because the mid-summer planting occurs shortly after hay harvest, which allows producers to generate crop income. A mid-summer planting also allows cover crop growth during the warm temperatures of summer and early fall. Planting cover crops in the spring is a good fit for producers with limited water availability because it takes advantage of stored winter soil moisture and cool, wet weather conditions during establishment. Planting in the fall is a good fit for producers who want to grow a full-season cash crop, such as hard red wheat, because fall planting allows them to plant after cash crop harvest. Fall planting is also desirable because the cover crop can prevent soil erosion during winter and early spring.

In both studies, potatoes were planted the year after cover crops were grown. Cover crop species included cool-season and warm-season species, seeded alone and in mixes. Cover crop species were selected based on their previous success in the local area or on previous research documenting success under similar growing conditions. A list of species evaluated is shown in table 1 . Cover crops were drill-seeded into a disked, packed seedbed using a drill cone planter with drill rows spaced 6 inches apart. Cover crop plant density was estimated using visual plant counts within a central rectangle in each plot, measuring 5 feet by 10 feet, when plants were 3 to 5 inches tall. Cover crops were grown under sprinkler irrigation, without synthetic fertilizer or pesticides. They were managed as a green manure by flail-mowing and disk-incorporating aboveground biomass at early flowering. Cover crop biomass in each plot was estimated from a quadrat of 5 feet by 10 feet. An aboveground biomass subsample was sent to a laboratory to estimate total nitrogen content in cover crop biomass. An untreated fallow treatment and a urea treatment were included in all trials for comparison purposes. The fallow treatment for spring cover crops was fallowed for 12 months before potato planting; the fallow treatment for mid-summer cover crops was fallowed, after harvest of the barley hay crop, for 8.5 months before potato planting; and the fallow treatment for fall cover crops and several amendments was fallowed, after harvest of the barley grain crop, for 6.5 months before potato planting. All fallow treatments, after weed suppression ratings were taken, were hand-weeded to prevent excessive weed growth and weed seed production.

Planting of the spring cover crop occurred in midApril. Mid-summer plantings occurred in late July, after a spring barley hay crop was grown. The fall cover crop planting occurred in mid-September, also after a spring barley grain crop was grown. Cover crops were incorporated into the soil at $50 \%$ flowering -71 to 77 days after planting for the spring planting, 70 to 76 days
TABLE 1. Cover crop seeding rate and inclusion in spring, summer and fall cover crop plantings

\begin{tabular}{|l|l|l|l|}
\hline Cover crop & $\begin{array}{c}\text { Seeding } \\
\text { rate }\end{array}$ & $\begin{array}{l}\text { Common planting } \\
\text { times }\end{array}$ & $\begin{array}{l}\text { Planting time in } \\
\text { trials }\end{array}$ \\
\hline Grasses & & & \\
\hline SX 17 sorghum sudangrass & $30 \mathrm{lb} / \mathrm{acre}$ & Summer & Summer \\
\hline Trical 141 spring triticale & $90 \mathrm{lb} /$ acre & Spring & Summer \\
\hline Trical 102 winter triticale & $90 \mathrm{lb} / \mathrm{acre}$ & Fall & Summer, fall \\
\hline Twin spring wheat & $70 \mathrm{lb} / \mathrm{acre}$ & Spring & Spring \\
\hline
\end{tabular}

Legumes

\begin{tabular}{lcll} 
AC Greenfix chickling vetch & $60 \mathrm{lb} / \mathrm{acre}$ & Spring, summer, fall & Summer \\
\hline Banner spring field pea & $172 \mathrm{lb} /$ acre & Spring, summer, fall & Summer \\
\hline Berseem clover & $20 \mathrm{lb} /$ acre & Summer & Summer \\
\hline Cowpea & $40 \mathrm{lb} / \mathrm{acre}$ & Summer & Summer \\
\hline Flex spring field pea & $120 \mathrm{lb} / \mathrm{acre}$ & Spring, summer, fall & Spring, summer, fall \\
\hline Hairy vetch & $50 \mathrm{lb} / \mathrm{acre}$ & Spring, fall & Summer \\
\hline Journey spring field pea & $147 \mathrm{lb} / \mathrm{acre}$ & Spring, summer, fall & Summer \\
\hline Koyote winter field pea & $154 \mathrm{lb} /$ acre & Fall & Summer \\
\hline Lana woollypod vetch & $60 \mathrm{lb} /$ acre & Spring, fall & Spring, summer, fall \\
\hline Nutrigreen winter field pea & $139 \mathrm{lb} /$ acre & Fall & Fall
\end{tabular}

\section{Mustards}

\begin{tabular}{|l|l|l|l|}
\hline Caliente 199 mustard & $10 \mathrm{lb} /$ acre & Spring & Spring, summer \\
\hline Nemat arugula & $6 \mathrm{lb} / \mathrm{acre}$ & Spring, fall & Spring, fall
\end{tabular}

Radish

Defender oilseed radish

\section{$50 / 50$ mixes}

Arugula and spring field pea

Flex spring field pea

Nemat arugula

Mustard and spring field pea

Caliente 199 mustard

Flex spring field pea

Mustard and woollypod vetch

Caliente 199 mustard

Lana woollypod vetch

Radish and spring field pea

Defender oilseed radish

Flex spring field pea

Triticale and vetch

Lana woollypod vetch

Trical 102 winter triticale
$15 \mathrm{lb} /$ acre Spring, fall

Spring, summer
Spring

$3 \mathrm{lb} / \mathrm{acre}$

$$
\text { Spring, fall }
$$

Spring

$5 \mathrm{lb} / \mathrm{acre}$

$60 \mathrm{lb} / \mathrm{acre}$

Spring, summer, fall

Summer

$5 \mathrm{lb} / \mathrm{acre}$

$30 \mathrm{lb} / \mathrm{acre}$

$7.5 \mathrm{lb} / \mathrm{acre}$

Spring, summer, fall

Summer

$60 \mathrm{lb} / \mathrm{acre}$

Fall

Fall
$60 \mathrm{lb} / \mathrm{acre}$
$30 \mathrm{lb} / \mathrm{acre}$

$45 \mathrm{lb} / \mathrm{acre}$ 
Grading potatoes at IREC. Potatoes were graded by counting all potatoes in each plot and mechanically sorting them by weight into five size classes based on U.S. grade and carton classes. after planting for mid-summer plantings and 230 days after planting for the fall planting. Fall-planted cover crops did not reach the flowering stage before incorporation. The reason for early termination of fall-planted cover crops was to allow 4 weeks between cover crop incorporation and potato planting and thus enable cover crop decomposition and prevent a green bridge. Total applied water for irrigated cover crop trials was 12 inches for the spring planting, 6 to 8 inches for midsummer plantings and 3.5 inches for the fall planting. Cover crop vigor was determined by visually evaluating plant canopy cover and height in the plot area, with a vigor score of 10 equal to the most vigorous growth and 1 equal to bare ground. Weed suppression ratings were determined by visually evaluating the density and height of weeds in each plot. A weed suppression rating equal to 10 represented zero weeds in the plot and 1 was equal to weed density and height similar to the unplanted bare-ground control. Weed suppression ratings were taken when weeds and cover crops were 6 to 10 inches tall. Weed biomass was measured in each plot at the time of cover crop harvest by hand-separating cover crop and weed plant material derived from the quadrat sample.

\section{Organic amendments}

Two amendment studies were conducted at IREC. One study evaluated fall-applied amendments in 2014 and another study evaluated amendments applied in fall 2016 and spring 2017. Amendments were applied by hand and disk-incorporated into the soil - in midSeptember for fall applications and in late April for spring applications. The tested organic amendments included chicken manure, steer manure, composted

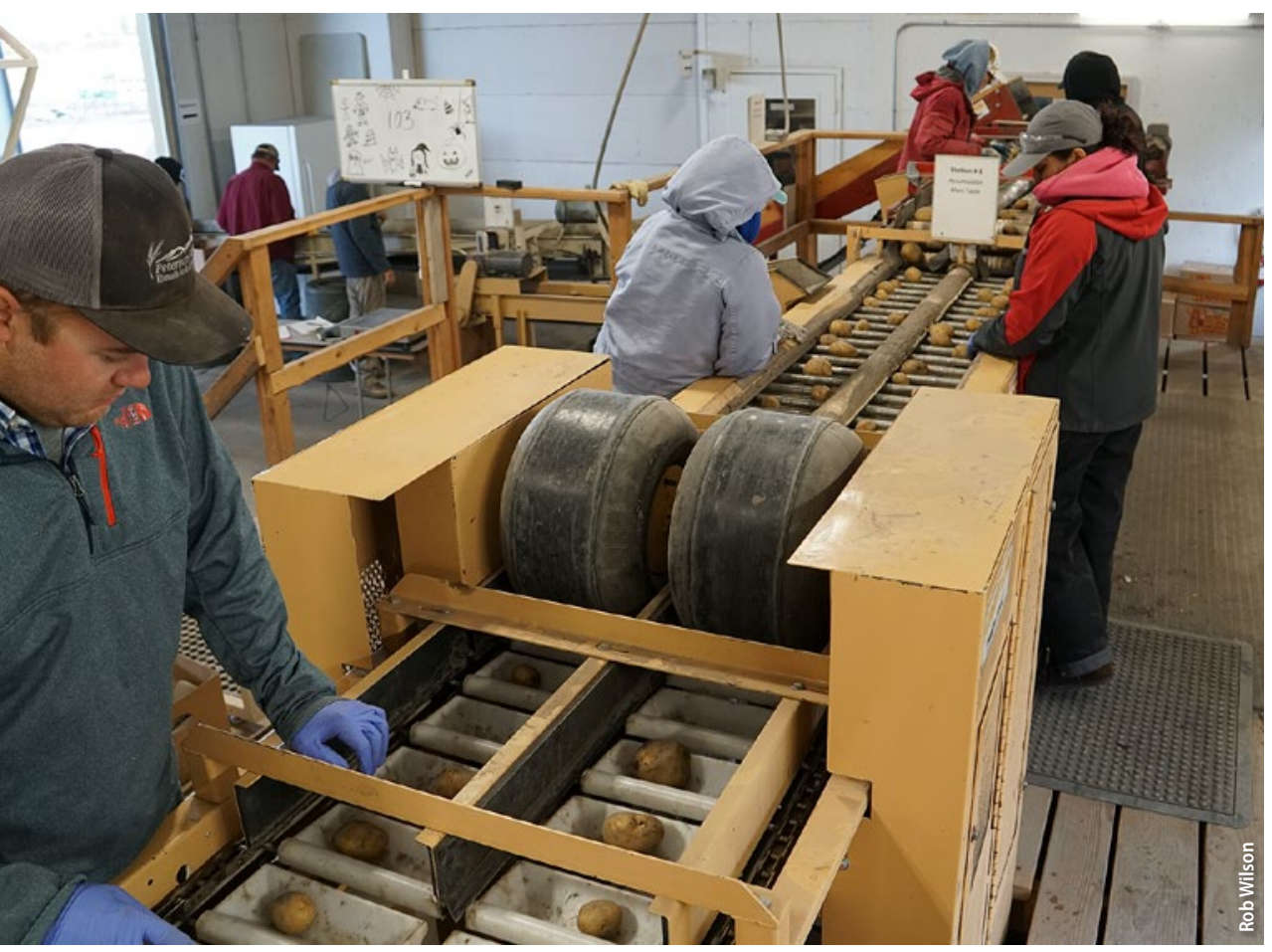

chicken manure and a compost mix using green waste and cow manure. Bloodmeal and soymeal were broadcast-applied and incorporated using a Lilliston cultivator after bed preparation and before planting. These two amendments were included to represent organic alternatives to quick-release synthetic nitrogen fertilizers such as urea. Amendment application rates were based on the products' moisture and nitrogen content, with the goal of applying 150 pounds of nitrogen per acre (assuming 100\% dry matter). Amendment application rates ranged from 1,100 pounds per acre for bloodmeal with $13 \%$ nitrogen to 10,000 pounds per acre for compost with $1.5 \%$ nitrogen. The nitrogen mineralization rates for the amendments varied and were not controlled in the experiment.

\section{Potato production}

Potatoes were planted over areas treated with cover crops, amendments and combinations of cover crops and amendments. Potatoes were also planted over areas treated with urea fertilizer and over untreated fallow areas. Planting occurred in the spring, without the use of synthetic fertilizers or pesticides. Preplant soil samples were taken at potato planting to confirm that supplies of phosphorus, potassium, sulfur and calcium were adequate to avoid deficiencies; all soil tests showed adequate nutrient levels according to University of California guidelines (CDFA 2015; Lang at al. 1999). Potato row spacing was 36 inches and seed spacing was 10 inches. The Russet Norkotah potato variety was evaluated in 2015 and the Yukon Gold variety was evaluated in 2017. Soil samples were collected from each plot shortly before planting to determine nitrate available at preplanting, as well as available ammonium and total nitrogen. Plot size was 12 feet by 40 feet; all sampling occurred in a middle area, measuring 6 feet by 30 feet, to avoid edge effects. The soil type at IREC is a Tulebasin mucky silty clay loam with $4.5 \%$ organic matter. To meet crop evapotranspiration needs, potatoes were irrigated with solid-set irrigation that entailed use of soil moisture monitors and an on-site CIMIS weather station.

Crop vigor was monitored multiple times during the growing season by visually evaluating plant canopy cover, height and color over the plot area, with a vigor score of 10 equal to plants in the plot with the highest canopy cover and a dark-green color and 0 equal to short, senesced, yellow plants. Petiole nitrogen was measured at early tuber bulking and at crop maturity. Potatoes from each plot were mechanically harvested and graded to determine fresh-market tuber yield and tuber quality. Potatoes were graded by counting all potatoes in each plot and mechanically sorting them by weight into five size classes based on U.S. grade and carton classes. Tuber quality was determined by counting and weighing all cull tubers that displayed rot, greening, knobs, growth cracks, irregular shape and irregular skin appearance. A 10-tuber subsample from each plot was evaluated for internal defects including 
hollow heart, brown spot bruise, vascular discoloration and specific gravity.

\section{Postharvest monitoring}

Available soil nitrogen (ammonium and nitrate) was measured after potato harvest to quantify remaining nitrogen at soil depths of $0-10$ inches and 10-20 inches. Winter wheat, a common rotation crop with potatoes, was planted in October after potato harvest. The flagleaf nitrogen content and the grain yield of winter wheat were measured for select treatments to estimate the enduring effects of treatments.

\section{Establishment, vigor and weed suppression}

Cover crop establishment in all trials was successful. Plant densities were measured at or above $80 \%$ of the seeding rate (data not shown), with two exceptions - a crop of cowpeas seeded in mid-summer (plant density of $73 \%$ ) and a crop of spring-seeded arugula (plant density of 50\%). Low plant density for spring arugula was probably due to planting too deep. Arugula requires a shallow seeding depth of less than 0.5 inch. Subsequent seedings of arugula at the correct seeding depth produced plant density higher than $80 \%$. Spring wheat, fall triticale, woollypod vetch, field peas, spring mustard and oilseed radish displayed rapid growth, high vigor and high weed suppression (table 2). Mixes of mustards and field peas or vetch, in 50/50 proportions, also had high vigor and high weed suppression. Spring-seeded arugula exhibited lower vigor and weed suppression than the other spring cover crops, likely due to the stand problems associated with excessively deep seeding.

Oilseed radish, mustards and grasses planted in mid-summer, after a spring barley crop, exhibited lower vigor and biomass than spring plantings (table 2). This effect was caused by a deficiency of plant-available nitrogen at planting; the mustards, radish and grasses had low nitrate in plant tissue during the early season (data not shown) and a low percentage of nitrogen biomass at harvest compared to spring plantings (table 3 ). Nitrate nitrogen in the top 10 inches of fallow plots averaged 17 parts per million (ppm) at the spring planting and below $5 \mathrm{ppm}$ at the mid-summer and fall plantings. These nitrate concentrations respectively correspond to approximately 28 and 8 pounds of nitrogen per acre in the top 10 inches of the profile. Many growers express interest in growing a spring barley or wheat crop for revenue before planting cover crops, but these results clearly show that adequate mineralized soil nitrogen is needed for non-legume cover crops to flourish. The idea that legumes might contribute nitrogen to non-legume cover crops in a mixed planting was not supported, as mustard, radish and grass grown in a mix with field peas and vetches had vigor and biomass similar to the single-species planting; the mix was instead dominated by field peas, which fixed their own nitrogen but did not share it with other species.
Cowpeas, berseem clover and sorghum-sudangrass planted in mid-summer died at the first killing frost in early September and failed to produce significant biomass (table 2). Field peas, woollypod vetch, mustard, oilseed radish and 50/50 mixes had high weed

TABLE 2. Cover crop vigor, weed suppression and biomass yield

\begin{tabular}{|c|c|c|c|}
\hline \multirow[b]{2}{*}{ Cover crop } & Vigor & $\begin{array}{c}\text { Weed } \\
\text { suppression }\end{array}$ & \multirow{2}{*}{$\begin{array}{c}\text { Biomass yield at } \\
\text { incorporation } \\
100 \% \text { dry tons/ } \\
\text { acre }\end{array}$} \\
\hline & \multicolumn{2}{|c|}{$1-10$ scale $; 10=$ best $^{*}$} & \\
\hline \multicolumn{4}{|l|}{ Grasses } \\
\hline $\begin{array}{l}\text { SX } 17 \text { sorghum-sudangrass } \\
\text { (summer) } t\end{array}$ & 7 & 5 & 0.8 \\
\hline Trical 102 winter triticale (fall) & 7 & 9 & 1 \\
\hline Trical 141 spring triticale (summer) & 6 & 5 & 0.4 \\
\hline Twin spring wheat (spring) & 8 & 8 & 3 \\
\hline
\end{tabular}

\section{Legumes}

\begin{tabular}{|llll}
\hline $\begin{array}{l}\text { AC Greenfix chickling vetch } \\
\text { (summer) }\end{array}$ & 7 & 8 & 2 \\
\hline Banner spring field pea (summer) & 8 & 8 & 2.8 \\
\hline Berseem clover (summer) & 4 & 5 & 1.4 \\
\hline Cowpea (summer) & 5 & 3 & 0.1 \\
\hline Flex spring field pea (spring) & 8 & 8 & 2.7 \\
\hline Hairy vetch (summer) & 8 & 8 & 2.2 \\
\hline Journey spring field pea (summer) & 8 & 8 & 2.5 \\
\hline Koyote winter field pea (summer) & 7 & 6 & 2.2 \\
\hline Lana woollypod vetch (fall) & 8 & 9 & 2.1 \\
\hline Lana woollypod vetch (spring) & 8 & 7 & 2.1 \\
\hline Lana woollypod vetch (summer) & 8 & 8 & 2.4 \\
\hline Nutrigreen winter field pea (fall) & 7 & 7 & 1.6 \\
\hline
\end{tabular}

\begin{tabular}{|c|c|c|c|}
\hline \multicolumn{4}{|l|}{ Mustards } \\
\hline Caliente 199 mustard (spring) & 7 & 8 & 2.3 \\
\hline Caliente 199 mustard (summer) & 6 & 9 & 0.8 \\
\hline Nemat arugula (spring) & 6 & 5 & 1.7 \\
\hline
\end{tabular}

Radish

\begin{tabular}{llll} 
Defender oilseed radish (spring) & 8 & 8 & 2.7 \\
\hline Defender oilseed radish (summer) & 5 & 9 & 0.4
\end{tabular}

\section{$50 / 50$ mixes}

Arugula and spring field pea (spring)

Mustard and spring field pea (spring)

Mustard and woollypod vetch

(summer)

Radish and spring field pea (summer)

Triticale and woollypod vetch (fall)

\begin{tabular}{|l|l|l|}
\hline 7 & 6 & 1.8 \\
\hline 8 & 8 & 2.2 \\
\hline 8 & 9 & 2.3 \\
\hline 8 & 9 & 1.7 \\
\hline 9 & 10 & 2.3 \\
\hline
\end{tabular}

* Cover crop vigor scale: $10=$ the most vigorous growth in study area and $1=$ bare ground. Weed suppression scale: $10=$ zer weeds and $1=$ weed density and height similar to those in the unplanted bare-ground control. Weed suppression ratings were determined by visually evaluating weed density and height in each plot.

† Information in parentheses represents planting time for presented data. 
suppression ratings in the mid-summer trial (table 2). Spring field pea varieties exhibited greater vigor and biomass than winter field pea varieties in mid-summer plantings (table 2).

\section{Cover crops' influence on nitrogen}

Field pea and vetch green manures contributed substantial nitrogen to the system, adding over 150 pounds - and in many cases over 200 pounds - of nitrogen per acre from aboveground biomass (table 3 ). The highest nitrogen contributor was spring-planted "flex" field peas, which added 306 pounds of nitrogen per acre. Berseem clover and cowpeas contributed less than 70 pounds of nitrogen per acre because Tulelake's short growing season was too cold for these species to reach maturity before frost. Several grass and mustard cover crops produced significant biomass, but their nitrogen content was less than half of that produced by most legume species (table 3). More than 150 pounds of nitrogen per acre were contributed by $50 / 50$ mixes of legumes and either grass or mustard.

Mineralized nitrogen (soil nitrate and ammonium) at the time of potato planting was correlated $(r=0.72)$ to added nitrogen from cover crops (table 3 ), suggesting that little nitrogen was lost to leaching or denitrification over the winter. Mineralized nitrogen in the top 10 inches of soil for most field peas and vetches was more than double that for non-legume cover crops. Aboveground biomass (leaves and stems) contained most of the nitrogen from legume green manure. Mineralized nitrogen at potato planting, in treatments that involved haying field peas' aboveground biomass

TABLE 3. Influence of added N from cover crops, amendments and controls on mineralized nitrogen at potato planting and early bulking

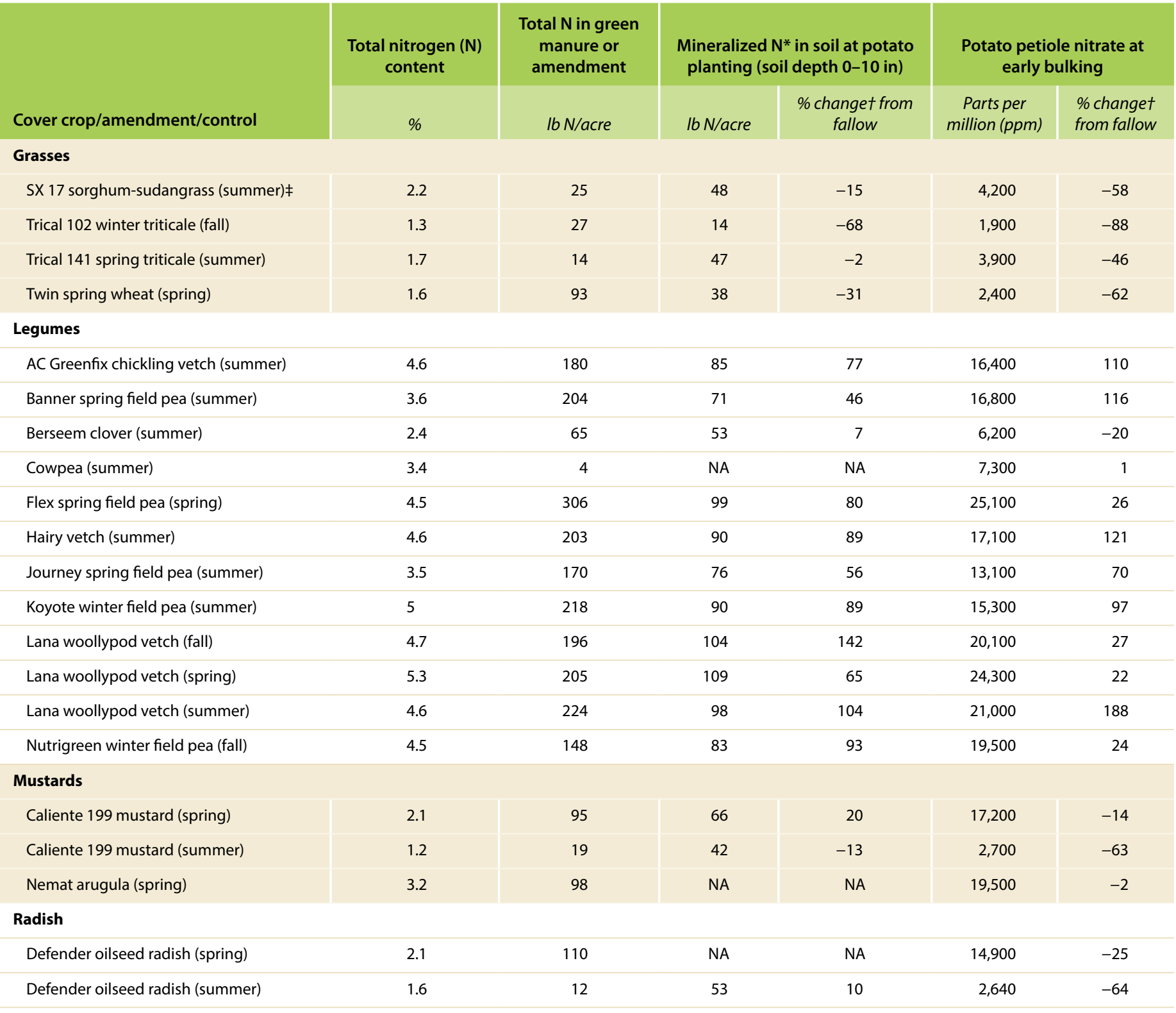


and removing it from the field (data not shown), was no different from fallow treatments. This is consistent with other studies (Kuo and Sainju 1997, 1998) demonstrating that aboveground biomass contains most of the nitrogen in legume cover crops. Mineralized nitrogen at potato planting in fallow treatments averaged 55 pounds of nitrogen per acre for spring fallow, 48 pounds per acre for mid-summer fallow and 43 pounds for fall fallow. Mustard, radish and sorghum-sudangrass resulted in mineralized nitrogen similar to that of fallow treatments, suggesting these cover crops had a neutral effect on soil nitrogen (table 3). Spring wheat and fall triticale resulted in lower mineralized nitrogen at potato planting than was measured in fallow treatments, likely because decomposition of grass residue tied up available nitrogen. Delayed release of nitrogen in potatoes is problematic because potatoes require adequate nitrogen in the early season for vegetative growth and tuber initiation.

Potato petiole nitrate at early bulking was used to evaluate in-season nitrogen availability. Legume cover crops resulted in much higher potato petiole nitrate at early bulking than did grasses; petiole nitrate for treatments with field peas and vetches was similar to petiole nitrate produced in conventional fertilizer controls (table 3). When comparing potato petiole nitrate in cover crop treatments to that in fallow treatments, legumes were higher, mustards were similar and grasses were lower (table 3).

One year after growing potatoes (and 2 years after cover crop production), flag leaf nitrogen in winter wheat was higher in plots that had received spring

TABLE 3. Influence of added $N$ from cover crops, amendments and controls on mineralized nitrogen at potato planting and early bulking

\begin{tabular}{|c|c|c|c|c|c|c|}
\hline \multirow[b]{2}{*}{ Cover crop/amendment/control } & \multirow{2}{*}{$\begin{array}{c}\text { Total nitrogen }(\mathrm{N}) \\
\text { content } \\
\\
\%\end{array}$} & \multirow{2}{*}{$\begin{array}{c}\text { Total } \mathrm{N} \text { in green } \\
\text { manure or } \\
\text { amendment }\end{array}$} & \multicolumn{2}{|c|}{$\begin{array}{l}\text { Mineralized } \mathrm{N}^{*} \text { in soil at potato } \\
\text { planting (soil depth } 0-10 \mathrm{in} \text { ) }\end{array}$} & \multicolumn{2}{|c|}{$\begin{array}{l}\text { Potato petiole nitrate at } \\
\text { early bulking }\end{array}$} \\
\hline & & & Ib N/acre & $\begin{array}{l}\% \text { changet from } \\
\text { fallow }\end{array}$ & $\begin{array}{c}\text { Parts per } \\
\text { million (ppm) }\end{array}$ & $\begin{array}{l}\% \text { changet } \\
\text { from fallow }\end{array}$ \\
\hline \multicolumn{7}{|l|}{$50 / 50$ mixes } \\
\hline Arugula and spring field pea (spring) & 5 & 178 & NA & NA & 21,700 & 9 \\
\hline Mustard and spring field pea (spring) & 4.2 & 187 & 82 & 49 & 20,900 & 5 \\
\hline Mustard and woollypod vetch (summer) & 3.3 & 150 & 69 & 44 & 14,100 & 93 \\
\hline Radish and spring field pea (summer) & 3.2 & 112 & 72 & 50 & 12,500 & 71 \\
\hline Triticale and woollypod vetch (fall) & 4.2 & 190 & 91 & 112 & 19,500 & 24 \\
\hline \multicolumn{7}{|l|}{ Manure and amendments } \\
\hline Composted chicken manure (spring) & 2.9 & 150 & 114 & 165 & 19,000 & 42 \\
\hline Composted chicken manure (fall) & 2.9 & 150 & 79 & 65 & 19,100 & 44 \\
\hline Dried steer manure (fall) & 0.9 & 150 & 51 & -7 & 9,680 & -15 \\
\hline Explorer $16-0-0$ soy protein (planting) & 16 & 150 & NA & NA & 20,500 & 44 \\
\hline Green waste/cow manure compost (fall) & 1.2 & 150 & 39 & -18 & 10,400 & -14 \\
\hline Perfect Organic Blend 4-4-4 pellets§ (fall) & 4.4 & 150 & 118 & 127 & 22,200 & 57 \\
\hline Pro-Pell-It! 13-0-0 bloodmeal (planting) & 13 & 150 & NA & NA & 22,600 & 46 \\
\hline Stutzman Nutri-Rich 4-3-2 pellets§ (fall) & 3.7 & 150 & 81 & 58 & 21,000 & 35 \\
\hline \multicolumn{7}{|l|}{ Controlsף } \\
\hline Fallow (amendment trial) & NA & 0 & 51 & 0 & 11,800 & 0 \\
\hline Fallow (fall cover crop trial) & NA & 0 & 43 & 0 & 15,800 & 0 \\
\hline Fallow (spring cover crop trial) & NA & 0 & 55 & 0 & 19,900 & 0 \\
\hline Fallow (summer cover crop trials) & NA & 0 & 48 & 0 & 7,530 & 0 \\
\hline Urea fertilizer $-75 \mathrm{lb}$ N/acre (planting) & 46 & 75 & NA & NA & 17,200 & 25 \\
\hline Urea fertilizer - $150 \mathrm{lb}$ N/acre (planting) & 46 & 150 & NA & NA & 23,600 & 72 \\
\hline $\begin{array}{l}\text { * Mineralized } \mathrm{N} \text { included } \mathrm{NO}_{3-\mathrm{N}} \text { and } \mathrm{NH}_{4-\mathrm{N}} \text {. } \\
\text { † Percentage change from untreated fallow. The mean valt } \\
\text { ₹ Information in parentheses represents cover crop planti } \\
\text { § Chicken manure is the primary ingredient in Stutzman } \mathrm{N} \\
\text { n Data for fallow and urea fertilizer treatments is reported }\end{array}$ & $\begin{array}{l}\text { cross studies is presented fo } \\
\text { ime or, for manures and ame } \\
\text {-Rich 4-3-2 and Perfect Orga }\end{array}$ & $\begin{array}{l}\text { atments replicated in mul } \\
\text { nents, time of incorporatic } \\
\text { Blend 4-4-4. }\end{array}$ & $\begin{array}{l}\text { le studies. } \\
\text { Treatments condu }\end{array}$ & at planting occurred aft & pring soil sampling. & \\
\hline
\end{tabular}


vetch and field pea treatments than in fertilizer controls and fallow treatments (data not shown). Plots that had been planted with field peas and vetches in mid-summer were associated with lower flag leaf nitrogen than plots that had received spring plantings of field peas

TABLE 4. Influence of 2014 summer-planted cover crops, 2014 fall-applied amendments and 2015 fertilizers applied at planting on 2015 Russet Norkotah potato yields

\begin{tabular}{|c|c|c|c|c|}
\hline & Total yield & US \# 1 yield & $\begin{array}{c}\text { Average } \\
\text { tuber } \\
\text { size }\end{array}$ & $\begin{array}{c}\text { Cull } \\
\text { yield }^{*}\end{array}$ \\
\hline Cover crop & $\begin{array}{c}\text { Hundred } \\
\text { weight/acre }\end{array}$ & $\begin{array}{l}\text { Hundred } \\
\text { weight/acre }\end{array}$ & $O Z$ & $\% t$ \\
\hline \multicolumn{5}{|l|}{ Grasses } \\
\hline SX 17 sorghum-sudangrass & 311 & 247 & 6.1 & 3.5 \\
\hline Trical 102 triticale & 351 & 285 & 6.7 & 3 \\
\hline \multicolumn{5}{|l|}{ Legumes } \\
\hline AC Greenfix chickling vetch & 397 & 313 & 7.3 & 4.7 \\
\hline Banner spring field pea & 378 & 284 & 6.8 & 7.9 \\
\hline Berseem clover & 344 & 267 & 6.5 & 3.8 \\
\hline Flex spring field pea & 388 & 294 & 7 & 6.4 \\
\hline $\begin{array}{l}\text { Flex spring field pea (harvested } \\
\text { for hay) }\end{array}$ & 324 & 225 & 5.6 & 5.1 \\
\hline Hairy vetch & 414 & 307 & 7.5 & 10 \\
\hline Journey spring field pea & 385 & 298 & 6.8 & 5.9 \\
\hline Koyote winter field pea & 357 & 256 & 7 & 10.1 \\
\hline Lana woollypod vetch & 428 & 339 & 8 & 6.9 \\
\hline Nutrigreen winter field pea & 381 & 287 & 6.9 & 5.9 \\
\hline
\end{tabular}

Manure and amendments

\begin{tabular}{|c|c|c|c|c|}
\hline Dried steer manure (fall)‡ & 394 & 285 & 6.5 & 11.9 \\
\hline $\begin{array}{l}\text { Explorer } 16-0-0 \text { soy protein } \\
\text { fertilizer at planting }\end{array}$ & 424 & 286 & 7.1 & 17.1 \\
\hline $\begin{array}{l}\text { Green waste/cow manure } \\
\text { compost (fall) }\end{array}$ & 383 & 284 & 6.5 & 10.8 \\
\hline $\begin{array}{l}\text { Perfect Organic Blend 4-4-4 } \\
\text { chicken manure (fall) }\end{array}$ & 423 & 274 & 7.3 & 18 \\
\hline $\begin{array}{l}\text { Pro-Pell-It! 13-0-0 bloodmeal at } \\
\text { planting }\end{array}$ & 423 & 290 & 7.2 & 15.6 \\
\hline $\begin{array}{l}\text { Stutzman Nutri-Rich 4-3-2 } \\
\text { chicken manure (fall) }\end{array}$ & 416 & 283 & 6.7 & 14.8 \\
\hline \multicolumn{5}{|l|}{$\begin{array}{l}\text { Untreated and conventional } \\
\text { fertilizer }\end{array}$} \\
\hline Untreated hand-weeded fallow & 358 & 261 & 6.1 & 7.6 \\
\hline $\begin{array}{l}\text { Urea fertilizer - } 75 \mathrm{lb} \text { N/acre } \\
\text { (planting) }\end{array}$ & 398 & 279 & 6.4 & 9.9 \\
\hline $\begin{array}{l}\text { Urea fertilizer - } 150 \mathrm{lb} \text { N/acre } \\
\text { (planting) }\end{array}$ & 405 & 285 & 6.6 & 12.2 \\
\hline Treatment effect $P$ value & 0.0001 & 0.3143 & 0.001 & 0.001 \\
\hline $\begin{array}{l}95 \% \text { confidence interval for mean } \\
\text { comparison }\end{array}$ & 34 & 36 & 0.6 & 5 \\
\hline
\end{tabular}

* Cull yield represents unmarketable tubers including those exhibiting green, rot, growth cracks, knobs and irregular shape. † Percentage of total yield.

‡ Information in parentheses represents time of incorporation for manures and amendments in 2014. and vetches. Grass cover crops were associated with the lowest leaf nitrogen, suggesting that the ability of grass decomposition to tie up nitrogen can be persistent. Visual growth differences were apparent throughout the winter wheat growing season; wheat in spring field peas and vetch cover crop treatments were taller and much greener than other treatments. This suggests that nitrogen release from legume cover crops can continue for more than 1 year and can potentially have cumulative effects in crop rotations.

\section{Amendments' influence on nitrogen}

Chicken manure amendments (composted chicken manure, Stutzman Nutri-Rich pellets and Perfect Organic Blend pellets) were the most effective fall-applied amendments for increasing soil nitrate levels at potato planting (table 3). Soil nitrate at potato planting in soil amended with chicken manure was greater than 75 pounds of nitrogen per acre (table 3), similar to levels in plots treated with field peas and vetches. Potato petiole nitrate levels for plots amended with chicken manure were over 19,000 ppm at early tuber bulking, similar to levels produced by many field peas and vetches. Potato petiole nitrate at early bulking for bloodmeal and soymeal amendments was similar to levels associated with both chicken manure and 150 pounds per acre of urea fertilizer (table 3).

Green waste compost applied at all rates, as well as composted steer manure, led to lower soil nitrate at potato planting than did chicken manure, and these amendments did not increase soil nitrate at potato planting compared to the fallow treatment (table 3). Green waste compost and steer manure did not increase potato petiole nitrate at early bulking and vine maturity (data not shown) compared to the fallow treatment, suggesting that nitrogen in these amendments mineralized too slowly for a single application to benefit a potato crop (table 3 ).

\section{Potato response to cover crops and amendments}

Potato establishment and early season vigor did not differ significantly among treatments, but differences in potato vigor were significant at row closure and tuber initiation (data not shown). Potato vigor differences were highly correlated $(r=0.86)$ with potato nitrate at early bulking. Treatments producing high potato petiole nitrate produced taller, greener potato plants than did treatments producing low potato petiole nitrate.

Russet Norkotah total potato yield, average tuber size and cull yield were influenced by cover crops and amendments (table 4) while Yukon Gold potato yield was similar for most treatments (data not shown). This trend was not surprising given that Russet Norkotah is more responsive to nitrogen fertilizer than Yukon Gold. For Russet Norkotah, vetch species (woollypod, hairy and chickling), chicken manures, steer manure, bloodmeal and soil protein fertilizer produced higher total potato yields than did the untreated fallow 
(table 4). These treatments, along with five field pea varieties, resulted in a larger average tuber size than did the untreated fallow (table 4).

Total yield for the treatment with 150 pounds per acre of urea fertilizer was similar to that produced with vetches, chicken manures and bloodmeal, suggesting that soil nitrogen availability was a primary factor in increasing potato yield (table 4). Nitrogen's important role is also supported by a strong positive correlation ( $r=0.873$ ) between total Russet Norkotah potato yield and potato petiole nitrate at early bulking. The $r$ value for this correlation equaled 0.656 when Russet Norkotah and Yukon Gold data were combined.

The only treatment-related effect on total Yukon Gold potato yield was that cover-cropping with spring wheat and fall triticale produced lower total yield than did cover-cropping with legumes (data not shown). Grass cover crop treatments led to numerically lower soil nitrogen at planting and lower potato petiole nitrate at early bulking, compared to the untreated fallow (table 3 ). This suggests that the low potato yield following grass cover crops could be due to nitrogen immobilization during potato growth and development.

Cover crop and amendment treatments did not cause a substantial increase in tubers with knobs or growth cracks in either Russet Norkotah or Yukon Gold (data not shown), but the percentage of cull potatoes based on total yield for Russet Norkotah differed among treatments (table 4). Both chicken manure treatments, as well as bloodmeal and soy protein, resulted in higher percentages of culls than did the untreated fallow. An increase in cull percentage often occurs as total yield increases, but Perfect Organic Blend chicken manure also produced a higher percentage of culls than did the treatment with 150 pounds per acre of urea fertilizer. All cover crop treatments led to a percentage of culls similar to or lower than was associated with the treatment with 150 pounds per acre of urea fertilizer (table 4).

Yukon Gold was chosen for the 2017 trials because Rhizoctonia black scurf and black dot tuber blemish, common problems for organic potato growers, are easy to see on yellow varieties. The severity of black scurf and black dot did not differ according to cover crop species, but in potatoes grown after spring-planted cover crops (averaged across cover crop species), 27\% exhibited black scurf - compared to $13 \%$ in potatoes grown after mid-summer and fall plantings of cover crops. On the other hand, spring plantings of cover crops (averaged across species) led to lower black dot severity on tubers than did mid-summer plantings (data not shown).

\section{Grower decisions}

Economic issues play a major role in the feasibility of using legume cover crops to boost soil nitrogen in a crop rotation. Organic growers must consider the opportunity cost involved in growing cover crops instead of a cash crop as well as the cost of applying an amendment such as chicken manure. The economic analysis required to weigh all benefits and lost opportunity costs is complex, and beyond the scope of this study, but a comparison of monetary costs shows that cover crop production is more expensive than synthetic fertilizer, similar to applying chicken manure and less expensive than applying bloodmeal and soy meal. The average cost of bulk urea fertilizer from local suppliers in Northern California in 2018 was $\$ 365$ per ton, or $\$ 60$ to supply one acre with 150 pounds of nitrogen (R. Wilson, unpublished data). The average cost of bulk dried poultry manure from local suppliers in Northern California was $\$ 145$ per ton, or $\$ 272$ dollars to supply one acre with 150 pounds of nitrogen (R. Wilson, unpublished data). The cost of bulk bloodmeal and soy meal represented a nitrogen cost of greater than $\$ 3.40$ per pound, or over $\$ 500$ to supply one acre with 150 pounds of nitrogen. The cost of certified organic bloodmeal, packaged in 50-pound bags, was greater than $\$ 7$ per pound of nitrogen, or more than $\$ 1,000$ to supply one acre with 150 pounds of nitrogen. The total cost of field pea and vetch production is estimated at \$175 dollars per acre, including the cost of seed, planting, irrigation, management and incorporation (R. Wilson, unpublished data).

\section{Cover crops versus amendments}

Vetch, field peas, bloodmeal, soy meal and chicken manure, because they produced potato yields and potato petiole nitrate similar to those produced in plots treated with 150 pounds per acre of urea fertilizer (tables 3 and 4), were feasible alternatives to synthetic fertilizer. Whether organic producers favor cover crops or chicken manure as a nitrogen source depends on several factors, including land availability and the opportunity to grow cash crops. Producers who grow high-value cash crops requiring a full growing season may favor amendments because they can be quickly applied after harvest or before planting. Producers with idle land or with time between cash crops during the growing season may prefer cover crops, as many legumes in this study added over 150 pounds of nitrogen per acre and provided multi-season carry-over of soil nitrogen, and also offer protection from soil erosion. For hay producers, it's extremely important to leave aboveground biomass from legume cover crops in place, instead of haying the residue, because most added nitrogen is contained in legumes' leaves and shoots rather than their roots. Regardless, both options offer benefits in soil health, and in our study the added nitrogen in both cases broke down into mineralized form in adequate amounts to meet early-season and late-season potato nitrogen needs. The economic benefit of using cover crops and chicken manure is more difficult to justify in conventional potatoes because, in our research, both practices entail higher costs and 
greater difficulty of application than synthetic fertilizer, which produced similar yields.

For organic potato production, using either grass cover crops or a one-time application of compost to increase soil nitrogen is difficult to justify economically. In our research, these treatments had a neutral or negative effect on soil nitrogen compared to fallow treatments. Organic nitrogen in these treatments failed to convert into mineralized form in adequate amounts to increase either potato yield or yield of wheat planted the year after potatoes. Mustard, arugula and radish had a neutral-to-positive effect on potato yield and nitrogen. Several Brassica species have also been shown to have biofumigation properties, although a reduction in soilborne potato diseases Rhizoctonia solani, Colletotrichum coccodes and Verticillium wilt was not evident in this study.
Fallowing for an entire year, starting in spring the year before growing potatoes, is another option that growers with idle land or limited water can consider. In this research, the spring fallow treatment resulted in mineralized nitrogen at potato planting similar to or higher than levels that resulted from the summer fallow and fall fallow treatments (table 3). In potatoes, the spring fallow treatment produced petiole nitrate at early bulking $(19,900 \mathrm{ppm})$ similar to that produced by a treatment with 150 pounds per acre of urea fertilizer following barley $(23,600 \mathrm{ppm})$. The additional nitrogen in the spring fallow treatment was likely related to natural mineralization of soil organic matter, as organic matter in Tulelake soils is naturally high (within a range of $4 \%$ to $8 \%$ ).

TABLE 5. Decision support for cover crops

\begin{tabular}{|c|c|c|c|c|}
\hline Land use objective & $\begin{array}{l}\text { Spring } \\
\text { planting* }\end{array}$ & $\begin{array}{l}\text { Mid-summer } \\
\text { planting* }\end{array}$ & $\begin{array}{l}\text { Fall } \\
\text { planting* }\end{array}$ & Comments \\
\hline Increase soil N & +++ & ++ & ++ & $\begin{array}{l}\text { Choose } \mathrm{N} \text {-fixing cover crop. Manage as a green manure. Field peas and } \\
\text { vetch are suitable for all planting times. Allow at least } 4 \text { weeks before } \\
\text { growing cash crop. }\end{array}$ \\
\hline Minimize loss of soil N & + & ++ & ++ & $\begin{array}{l}\mathrm{N} \text { from spring cover crop has the highest potential to be lost over the } \\
\text { winter, although results from this study did not show significant winter } \\
\text { losses. Wheat grown the year after potatoes captured soil } \mathrm{N} \text { from spring } \\
\text { cover crops grown } 2 \text { years prior. }\end{array}$ \\
\hline Scavenge soil nutrients & +++ & ++ & +++ & $\begin{array}{l}\text { Deep-rooted cover crops are effective at capturing nutrients if soil } \\
\text { testing indicates elevated levels located below the crop root zone. } \\
\text { Consider manure application if phosphorus or potassium is deficient at } \\
\text { all soil depths. Avoid double-cropping non-legume crops if soil } \mathrm{N} \text { is low. }\end{array}$ \\
\hline Suppress weeds & +++ & + & ++ & $\begin{array}{l}\text { Choose a vigorously growing cover crop. Vetch, field peas, mustard } \\
\text { and spring and fall small grains provided good weed suppression. Poor } \\
\text { cover crop growth or overirrigation can lead to an increase in weeds } \\
\text { the following season. Mid-summer plantings resulted in elevated weed } \\
\text { populations in potato for multiple species. }\end{array}$ \\
\hline Build soil organic matter & +++ & +++ & +++ & $\begin{array}{l}\text { Choose cover crop with high biomass. Cover crops must be grown for } \\
\text { several years to produce a significant change in soil organic matter. }\end{array}$ \\
\hline Prevent soil erosion & + & ++ & +++ & $\begin{array}{l}\text { Wind and water erosion is most problematic in winter and early spring } \\
\text { in northeast California. Don't incorporate aboveground residue if } \\
\text { preventing soil erosion is a high priority. }\end{array}$ \\
\hline Minimize need for irrigation & ++ & + & +++ & $\begin{array}{l}\text { Spring and fall cover crops take advantage of natural precipitation } \\
\text { events and offer the best chance of success on dry lands. Irrigation } \\
\text { to establish cover crops is recommended if significant rainfall is not } \\
\text { predicted. Mid-summer plantings require irrigation due to low summer } \\
\text { rainfall. }\end{array}$ \\
\hline $\begin{array}{l}\text { Potential for double- } \\
\text { cropping }\end{array}$ & + & ++ & ++ & $\begin{array}{l}\text { The region's short growing season limits opportunities to double-crop. } \\
\text { In this research, spring and summer plantings of cover crops took } 70 \text { to } \\
80 \text { days to reach the flowering stage. It is recommended that growers } \\
\text { allow at least } 4 \text { weeks after cover crop incorporation before planting a } \\
\text { cash crop. }\end{array}$ \\
\hline Increase potato yield & +++ & ++ & ++ & $\begin{array}{l}\text { Spring-planted cover crops with a summer fallow period resulted in the } \\
\text { highest potato yield, averaged across cover crop species. }\end{array}$ \\
\hline Suppress potato diseases & + & + & + & $\begin{array}{l}\text { Many cover crops are hosts of plant diseases. It is important to allow } \\
\text { at least } 4 \text { weeks after cover crop incorporation before planting a cash } \\
\text { crop to prevent the cover crop from serving as a green bridge for crop } \\
\text { diseases. In this research, cover crops had a neutral effect on potato } \\
\text { diseases when compared to the fallow treatment. Fall cover crops had } \\
\text { the lowest level of Rhizoctonia on tubers. }\end{array}$ \\
\hline
\end{tabular}




\section{Cover crop planting times}

Land managers who decide to grow cover crops often ask what time of year is optimal for planting them. The answer depends on land use objectives and the desired cover crop species. Table 5 is a decision support tool to help land managers weigh the benefits of different cover crop planting times. In this research, spring planting averaged across species resulted in fewer weeds, more tubers per plant and higher potato yields than did mid-summer and fall plantings (data not shown). Midsummer and fall plantings resulted in slightly less $R h i$ zoctonia black scurf than did spring plantings. These planting times also offer greater flexibility for doublecropping than does spring planting.

\section{Research recommendations}

Cover crops and amendments offer growers an effective way to increase mineralized soil nitrogen for organic potato production. In this research, use of both cover crops and amendments resulted in potato yields and potato quality similar to those achieved through use of conventional nitrogen fertilizer, without unacceptable outcomes related to pests. Results related to nitrogen are likely transferrable to other nitrogen-demanding crops grown in northeast California, including small grains and onions. Additional research is needed to address benefits and disadvantages involved in repeated use of cover crops and amendments over the long term (5 to 10 years). Research into long-term effects would be beneficial because many organic producers keep land in organic status for more than 5 years before rotating it back to conventional production. Research that examines organic fertilizer options for supplementing nutrients other than nitrogen is also needed. This is especially true for forage crops like alfalfa because such crops remove from the soil large amounts of phosphorus and potassium that are not returned after hay harvest. CA
R. Wilson is UC Cooperative Extension (UCCE) Farm Advisor at UC ANR Intermountain Research and Extension Center (Intermountain REC); D. Culp is Principal Superintendent of Agriculture at Intermountain REC; S. Peterson is Senior Farm Machinery Mechanic at Intermountain REC; K. Nicholson is Staff Research Associate at Intermountain REC; and D. Geisseler is UCCE Specialist in Nutrient Management in the Department of Land, Air and Water Resources at UC Davis.

\section{References}

Alva A. 2004. Potato nitrogen management. J Veg Crop Prod 10(1):97-132. https://doi. org/10.1300/J068v10n01_10 [CDFA] California Department of Food and Agriculture. 2015 California fertilization guidelines: potatoes. https://apps1. cdfa.ca.gov/FertilizerResearch/ docs/Potato.html (accessed Dec. 1, 2018)

Duru M. 1987. Effect of animal manure on phosphorus and potassium content of herbage. In: Animal Manure on Grassland and Fodder Crops: Fertilizer or Waste? Developments in Plant and Soil Science (30). Van Der Meer HG, Unwin RJ, Van Dijk TA, Ennik GC (eds.). Dordrecht: Springer. p. 351-3. https://doi. org/10.1007/978-94-009-3659 1_36

Fageria NK, Baligar VC, Bailey BA. 2005. Role of cover crops in improving soil and row crop productivity. Commun Soil Sci Plan 36(19-20):2733-57. https:// doi.org/10.1080/00103620500 303939

Finckh MR, Schulte-Geldermann E, Bruns C. 2006. Challenges to organic potato farming: disease and nutrient management. Potato Res 49(1):27-42. https://do org/10.1007/s11540-006-9004-3
Gimsing AL, Kirkegaard JA. 2009. Glucosinolates and biofumigation: fate of glucosinolates and their hydrolysis products in soil. Phytochem Rev 8(1):299-310. https://doi.org/10.1007/s11101008-9105-5

Hartz TK, Mitchell JP, Giannini C. 2000. Nitrogen and carbon mineralization dynamics of manures and composts. HortScience 35(2):209-212. https://journals. ashs.org/hortsci/view/journals/ hortsci/35/2/article-p209.xml

Hemayati SS, Akbar MJ, Ghaemi A, Fasahat P. 2017. Efficiency of white mustard and oilseed radish trap plants against sugar beet cyst nematode. Appl Soil Ecol 119:192-6. www.science direct.com/science/article/pii/ S092913931730392X

Kaspar TC, Singer JW. 2011. The use of cover crops to manage soil. US Department of Agriculture: Agricultural Research Service. http://digitalcommons. unl.edu/cgi/viewcontent.cgi? article $=2387 \&$ context $=$ usdaar sfacpub

Klonsky K, Greene CR. 2005. Widespread adoption of organic agriculture in the US: Are market-driven policies enough? American Agricultural Economics Association Annual Meeting, July 24-27, 2005. Providence, Rhode Island. http://ageconsearch.umn.edu/record/19382 files/sp05kl05.pdf
Kuo S, Sainju UM. 1997. Winter cover cropping influence on nitrogen in soil. Soil Sci Soc Am J 61(5):1392-9.

Kuo S, Sainju UM. 1998. Nitrogen mineralization and availability of mixed leguminous and non-leguminous cover crop residues in soil. Biol Fert Soils 26(4):346-53.

Lang NS, Stevens RG, Thomton RE, et al. 1999. Potato nutrient management for Central Washington. Pullman, Washington: Washington State University Cooperative Extension. Publication EB1871. https://research.wsu-

libs.wsu.edu/xmlui/bitstream/ handle/2376/6896/eb1871 pdf? sequence=1\&isAllowed =y Larkin RP, Griffin TS, Honeycutt CW. 2010. Rotation and cover crop effects on soilborne potato diseases, tuber yield and soil $\mathrm{mi}$ crobial communities. Plant Dis 94(12):1491-1502. https://do org/10.1094/PDIS-03-10-0172

Larney FJ, Blackshaw RE. 2003. Weed seed viability in composted beef cattle feedlot manure. J Environ Qual 32(3):1105-13. www.ncbi.n/m.nih.gov/ pubmed/12809312

Lazicki P, Geisseler D, Horwath WR. 2016. Potato production In California. California Department of Food and Agriculture. https://apps1.cdfa.ca.gov/

FertilizerResearch/docs/

Potato_Production_CA.pdf
Lynch DH, Sharifi M, Hammermeister A, Burton DL. 2012. Nitrogen management in organic potato production. In: Sustainable Potato Production: Global Case Studies. He Z et al. (eds.). Berlin/Heidelberg: Springer. https://link.springer. com/content/pdf/10.1007/97894-007-4104-1_12.pdf

Möller K. 2018. Soil fertility status and nutrient input-output flows of specialised organic cropping systems: a review. Nut Cycl Agroecosys 112(2):147-64. https://doi.org/10.1007/s10705018-9946-2

Sharma-Poudyal D, Paulitz

TC, du Toit LJ. 2016. Timing of glyphosate applications to wheat cover crops to reduce onion stunting caused by Rhizoctonia solani. Plant Dis 100(7):1474-81. https:// apsjournals apsnet.org/doi/ pdf/10.1094/PDIS-10-151234-RE

Sincik M, Turan ZM, Göksoy AT. 2008. Responses of potato (Solanum tuberosum L.) to green manure cover crops and nitrogen fertilization rates. Am J Potato Res 85(5):390-1.

https://link.springer.com/ article/10.1007/s12230-008 9043-1
Stark J, Westermann D, Hopkins B. 2004. Nutrient management guidelines for Russet Burbank potatoes. Moscow, Idaho: University of Idaho Cooperative Extension. Bulletin 840. www extension.uidaho.edu/ publishing/pdf/BUL/BUL0840. pdf

Sullivan DM, Andrews ND. 2012. Estimating plant-available nitrogen release from cover crops. Corvallis, Oregon: Pacific Northwest Extension. http:// ir.library.oregonstate.edu/xmlui/ bitstream/handle/1957/34720/ pnw636.pdf

[USDA] U.S. Department of Agriculture. 2017. Certified organic survey: 2016 summary. www. nass.usda.gov/Publications/ Todays_Reports/reports/census17.pdf

Whalen JK. 2014. Managing soil biota-mediated decomposition and nutrient mineralization in sustainable agroecosystems. Adv Agriculture. Article 384604. https://hindawi.com/journals/ aag/2014/384604

Wyland LJ, Jackson LE, Chaney WE, et al. 1996. Winter cover crops in a vegetable cropping system: impacts on nitrate leaching, soil water, crop yield, pests and management costs. Agr Ecosyst Environ 59:1-17. https://pdfs. semanticscholar.org/b324/ d3f8a27f8128b3d062fa4905b66fdea53612.pdf 